\title{
Selectively Forgetting Baudrillard: Rescuing Praxis from the Wreckage
}

\author{
Richard Gilman-Opalsky ${ }^{1}$
}

I argue that Jean Baudrillard's post-1970s work makes numerous wrong turns from the point of view of a philosophy of praxis. While Baudrillard's work is indispensable for the evolution of a critical theory of capitalism and its culture, his attack on the viability of political projects and normative philosophy must be refuted. I argue for a theory that retains a commitment to counteracting tendencies toward acquiescence and reconciliation-for theory in the service of rethinking revolution. [Article copies available for a fee from The Transformative Studies Institute. E-mail address: journal@transformativestudies.org Website: http://www.transformativestudies.org (C2010 by The Transformative Studies Institute. All rights reserved.]

KEYWORDS: Jean Baudrillard, Socialism, Social Theory, Political Philosophy, Radical Politics, Postmodernism, Poststructuralism.

\section{A CRITIQUE IN BROAD STROKES}

I would not want to say "forget Baudrillard" in the spirit of Baudrillard's 1977 essay Forget Foucault, unless I could command selective memory. Much of what Baudrillard has done is worth remembering, and against his own advice, some of it is even worth using as the Autonomia Move-

\footnotetext{
${ }^{1}$ Richard Gilman-Opalsky, Ph.D., is Professor of Political Philosophy in the Department of Political Science at the University of Illinois at Springfield. Dr. Gilman-Opalsky earned his Ph.D. in Political Science at The New School for Social Research. His MA (The New School for Social Research) and BA (Hofstra University) are in Philosophy. Dr. Gilman-Opalsky's research areas include the history of political philosophy, continental and contemporary political theory, socialist philosophy, and poststructuralism. Dr. Gilman-Opalsky is the author of Unbounded Publics: Transgressive Public Spheres, Zapatismo, and Political Theory (Lexington Books, 2008), as well as numerous articles. Address correspondence to: Richard Gilman-Opalsky, One University Plaza, MS PAC 360, University of Illinois, Springfield, Springfield, Illinois 62703-5407; e-mail: rgilm3@uis.edu.
} 